\title{
STUDIES ON COMPOSITION AND POPULATION DENSITY OF ZOOPLANKTONS IN KORADI POWER PLANT LAKE, MAHARASHTRA, INDIA
}

\author{
A.V.Dorlikar \\ P.G. Department of Zoology and Research Academy, Sevadal College for Women, Nagpur- \\ 440024, India \\ Corresponding Author: E-Mail address: ajaydorlikar@gmail.com
}

\begin{abstract}
:
In the present study an attempt has been made to investigate composition, abundance and population density of zooplanktons during November 2017 to January 2018 for three months to assess the water quality in Koradi Power Plant Lake. During entire study 19 genera belonging to four major groups were reported i.e. Rotifera, Cladocera, Copepoda and Ostracoda. Zooplanktons were present in the following order of dominance; Cladocera > Rotifera > Copepoda > Ostracoda. Pollution-tolerant taxa Brachionus, Moina, Bosmina, Keratella dominated in the lake. The adiversity indices were calculated to assess the species richness. Shannon-Weiner index was in between 3.97 to 4.08 indicating lake preserves rich plankton diversity. Equitability index was 0.93 to 0.96 indicating even distribution of the species.
\end{abstract}

Keywords: Zooplanktons, Koradi Power Plant Lake, a-diversity indices, Shannon-Weiner index

\section{INTRODUCTION:}

The water of Koradi Power Plant Lake is highly polluted due to discharge of various pollutants from the power generation plant. Thus water of this lake becomes unfit for drinking and domestic purpose. Plankton is an important component of ecosystem due to their key role in the turnover of organic matter and energy through the ecosystem (Telesh, 2004). Zooplanktons form an important link in food web of a freshwater ecosystem, whose main function is to act as primary and secondary links in the food chain (Hutchinson, 1957). Zooplanktons are the important bioindicators of water pollution and eutrophication (Ferdous and Muktadir, 2009; Kane et al., 2009; Lodi et al., 2011). Studies on species composition and abundance of water bodies are necessary to obtain basic knowledge on the biodiversity of zooplankton of a particular lake. Therefore, the aim of the present study was to analyse the zooplankton community and their abundance in Koradi Power Plant lake.

\section{METHOD AND MATERIAL:}

\subsection{Study area}

The lake selected under investigation is known as "Koradi Power Plant Lake". Koradi Power Plant lake is one of the fresh water lake situated near Jagdamba Temple Koradi, (Fig.1) 15 kilometres away from the Nagpur city (790.05' 53.57" E latitude, 210.15' $29.20^{\prime \prime} \mathrm{N}$, longitude and $290 \mathrm{~m}$ (M.S.L) altitude).

\subsection{Collection of sample}

Sample collection was carried out monthly from November 2017 to January 2018. Zooplankton samples were collected by filtering 50 liters of the lake water through standard plankton nylon net with mesh size $55 \mu \mathrm{m}$ during the early morning between 7.00 to 8.00 am. The concentrated samples were preserved in $5 \%$ formalin soon after the collection. Identification was carried out by using standard literature. The recorded species were identified following Ward and Whipple, 1959; Edmondson, 1959; Mizuno, 1964; Dussart,1969; Alfred et al., 1973; Harding and Smith,1974; Kolisko,1974; Koste ,1978; Victor and Fernando, 1979; Adoni et al., 1985; Mizuno and Takahashi ,1991; Battish ,1992; Reddy,1994; Michel and Sharma,1998 and Dhanapathi, 2003. Quantitative 
analysis and evaluations were carried out using Sedgwick Rafter plankton counting cell (Welch, 1948 and Edmondson, 1959).

Seven indices were used to estimate zooplankton diversity and species richness. Species diversity index was calculated based on Simpson (1949) and Shannon-Weiner(1949) ; richness index was adopted by Margalef (1951) and Menhinic (1964) and equitability Index by Magurran(1988). Dominance index or Simpson's index of diversity was calculated using formula 1- Simpson index. The percentage relative abundance of the specimens was estimated by direct count.

\section{RESULTS AND DISCUSSION}

\subsection{Composition of Zooplanktons at Koradi Lake}

Composition of zooplanktons at Koradi

Power Plant Lake is shown in Table 1. Two main Zooplanktonic groups observed during the entire study in Koradi Power Plant lake were Rotifers and Arthropoda. The Arthropods again categorized into three main taxa, i.e. Cladocera, Copepoda and Ostracoda.

Among Rotifers, total 7 species representing 02 families and 03 genera were observed and identified from Koradi Power Plant Lake. Among family Brachionidae 02 genera and 06 species have been recorded. These were Branchionus falactus, Branchionus angularis, Branchionus diversicornis, Branchionus plicatilis, Branchionus urceolaris, Keratella vulga . Family Lecanidae was represented by only single genus that is Lecane arculata. Among rotifers Branchionus falactus and Keratella vulga occurred as most abundant species. During the present study Rotifera stand second in order of population density.

Among Cladocera, total 6 species representing 04 families and 06 genera were reported. Family Bosminidae is represented by only one genus that is Bosmina longirostris. Family Chydoridae is represented by two species that are Alona rectangula and Chydorus species. Family Daphniidae is represented by two species that are Daphnia pulex and Ceriodaphnia species. Family Moinidae is represented by single species that is Moina micrura. Among cladocera Alona rectangula, Daphnia pulex and Moina micrura occurred as most abundant species. During the present study Cladocera stand first in order of population density.

Among Copepoda, total 4 species representing 02 families and 04 genera were observed. Family Cyclopidae is represented by three genera that are Cyclops, Mesocyclops and Nauplius where as family Diaptomidae is represented by single genera that is Diaptomus. Among copepoda Cyclops and Diaptomus occurred as most abundant species. During the present study Copepoda stand third in order of population density.

Among ostracoda, total 02 species representing single family and 02 genera were observed. Family Cyprididae represents both the genera that are Cypris and Stenocypris. Among ostracods and Cypris occurred as most abundant species. During the present study Ostracoda stand fourth in order of population density.

\subsection{Population Density of Zooplanktons}

Zooplankton population density in the Koradi Power Plant lake can be represented as Cladocera $>$ Rotifera $>$ Copepoda $>$ Ostracoda. During present study density of zooplankton was 244, 290 and 252 per litre during the month of November, December and January respectively (Table.2).

Relative biovolume of Rotifera, Cladocera, Copepoda and Ostracoda in percentage was observed to be 25:43.44:22.95: 8.60 in November, 24.13:38.96:24.82:12.06 in December and 26.19:37.30:24.20:12.30 in January respectively (Fig. 2)

3.3 a- diversity indices of Zooplanktons in
Koradi Lake:
a- diversity indices of zooplaktons in Koradi
Power Plant lake is shown in table 3. The


Simpson's diversity indices (D) for net zooplankton species demonstrated high $\mathrm{D}$ scores ranging 0.9302 to 0.9395, Berger parker Dominance Index was in the range of 0.09 to 0.12, Margalef Richness Index was in the range of 3.17 to 3.27 and Shanon-Weiner Index was in the range of 3.97 to 4.08 indicating lake preserves rich plankton diversity. In Koradi Power Plant lake species evenness ranged from 0.93 to 0.96 and monthly differences were small. Thus, in terms of Evenness, there is even distribution of zooplankton species in Koradi Power Plant lake.

Planktonic animals are called Zooplankton and the planktonic plants are called Phytoplankton. Zooplanktons are the heterotrophic type of plankton. Zooplankton are one of the most important biotic components influencing all the functional aspects and plays a vital role in food chain, nutrient recycling and energy flow in the aquatic ecosystem (Altaff, 2004, Park and Shin, 2007 and Datta, 2011,). Zooplankton constitutes important food item of many omnivorous and carnivorous fish (Sharifun, 2007). Zooplankton provides the necessary amount of protein required for rapid growth and development of different organs of fishes (Islam, et al., 2007). Planktonic studies are very important to determine the nature of the lake. Due to short life cycle, zooplankton communities often respond quickly to environmental change (Sharma et al., 2007). Zooplanktons are sensitive to pollutants and hence they act as bio indicator of water bodies (Sivalingam et al., 2013).

Among Zooplanktons 19 species belonging to different taxonomic groups were identified, of which 7 Rotifers, 6 Cladocerans, 4 Copepods and 2 were Ostracodons. Maxima of Zooplankton in the month of December and January can be attributed to the favourable temperature and availability of abundant food in the form of bacteria, nanoplankton and suspended detritus.
Among these Cladocerans were dominant during the entire study period. Cladocera are important diet for Zooplanktivorous fish (Christoffersen et al., 1993; Balayla and Moss, 2004). Alona rectangula, Daphnia pulex and Moina micrura were the main dominant cladocerans in Koradi Lake, while other species remain rare. Such observations are in agreement with Edmondson (1959) who stated that in limnetic regions, the cladoceran populations are rich in density, poor in species diversity.

Rotifera stands second in order of population density. There are 2030 Rotifera species present throughout the world (Segers, 2007) which inhabits the diverse zones in an aquatic ecosystem (Pejler, 1995). Generally population of Rotifer increases during Summer season due to increased rate of decomposition of organic matter in summer season (Malhotra et al., 1987). Presence of pollution tolerant taxa like Brachionus, Keratella and Lecane spp. indicate polluted water (Patrick, 1950) of the Koradi Power Plant lake.

Copepods are mainly herbivorous, although some species are omnivorous and carnivorous. Among Copepoda Cyclops and Diaptomus occurred as most abundant species. Copepods are generally regarded as pollution sensitive as they disappear in polluted water (Verma, 1967). However Cyclops is a dominant genus of Copepoda which is tolerant to the pollution.

During the present study Ostracoda stands fourth in order of population density. Among Ostracods two species have been represented, that are Cypris and Stenocypris. Higher abundance of Ostracoda during the Winter may be due to high concentration of dissolved oxygen in water which favours the growth of Ostracoda.

\section{REFERANCE :}

Adoni, A., Joshi,D.G., Gosh,K., Chourasia, S.K, Vaishya, A.K., Yadav, M. and Verma, H.G. (1985). A work book on limnology (Pratibha Publisher) Sagar. 
Alfred, J.R.B., Bricice,S., Issac,M.L., Michael,R.G., Rajendran,M., Royan,J.P, Sumitra, V. and Wycliffe, J. (1973). A guide to the study of freshwater organisms. J. Madras Univ. Suppl., 1: 103-151.

Altaff, K.A. (2004). Manual of zooplankton, UGC, New Delhi., 155 pp.

Balayla, D.J. and Moss, B. (2004). Relative importance of grazing on algae by plantassociated and openwater microcrustacea (Cladocera). Archiv. fur Hydrobiol., 161: 199224.

Battish, S.K. (1992). Freshwater zooplankton of India. Oxford and IBH Publishing Co. Pvt. Ltd, Delhi.

Christoffersen, K., Riemann, B., Klysner, A. and Sondergaard, M. (1993). Potential role of fish predation and natural populations of zooplankton in structuring a plankton community in eutrophic lake water. Limnol. Oceanogr., 38: 561-573.

Datta, T. (2011). Zooplankton diversity and physico-chemical conditions of two wetlands of Jalpaiguri district, India. Int. J. Appl. Biol. Pharma. Tech., 2 (3): 576-583.

Dhanapathi, M.V.S.S.S. (2003). Rotifers from Andhra Pradesh, India- III. Hydrobiologia. 48(1): 9-16.

Dussart, B.(1969) Les Copepodes des eaux continentales,2.Cyclopoides et Bio-logie: N. Boubee (ed.) Paris, 292pp.

Edmondson, W. T. (1959). Freshwater biology. $2^{\text {nd }}$ edn. John Wiley \&Sons, New York, USA. $1248 \mathrm{p}$.

Ferdous, Z. and Muktadir, A. K. M. (2009). A Review: Potentiality of Zooplankton as Bioindicator. American Journal of Applied Sciences. Vol. 6 (10): 1815-1819.

Harding, J.P. and Smith, W.A. (1974) A key to the British freshwater cyclopoid and calanoid copepods. Scientific Publications of the Freshwater Biological Association, No. 18 .

Hutchinson, G.E. (1957). A treatise on limnology: Vol I and II, Geography, Physics and Chemistry. John Wiley Inc. New York, 1015.

Islam, A.B.M.W., Manira,M.S., Rahman, M.M. and Zaman,M. (2007). Zooplankton of two Shrimp Farms at Khulna, Bangladesh,Sou. Asi $J$ of Agri. 2(1\&2): 117-122.
Kane, D. D., Gordon, S. I., Munawar, M., Charlton, M. N. and Culver, D. A. (2009). The Planktonic Index of Biotic Intergrity $(\mathrm{P}-$ IBI): An Approach for Assessing Lake Ecosystem Health. Ecological Indicators, Vol. 9: 1234-1247.

Kolisko, R.A. (1974). Plankton Rotifers Biology and Taxonomy. Die Binnengewasser. Volume XXVI / I. Supplement, Stuttagart. 146pp.

Koste, R.A. (1978). Die Radertiere Mitteleuropas I. Textband. Berlin, Stuttgart, 670pp.

Lodi,S., Vieira, L. C. G., Velho, L. F. M., Bonecker, C. C., de Carvalho, P. and Bini, L. M. (2011). Zooplankton Community Metrics as Indicators of Eutrophication in Urban Lakes. Natureza \& Conservação, Vol. 9 (1): 87-92.

Magurran, A.E. (1988). Ecological Diversity and Its Measurement. Princeton University Press, Princeton, New Jersey.

Malhotra,Y.R., Dutta, S.P.S. and Suri, S.N. (1987). Limnology of fish pond in regional research laboratory. Jamu. Matsya. 12-13; 174-177.

Margalef, D.R. (1951). Diversidad de especies en les communideades natural Public Institutte of Biologic, Barcelonia 9: 5-27.

Menhinick E.P. (1964). A comparison of some species-individuals diversity indices applied to samples of field insects. Ecology. 45: 859861.

Michael , R.G. and Sharma, B.K. (1998). Fauna of India and adjacent countries. Indian cladocera (crustacea: Branchipoda: Cladocera). Zoological Survey of India. 262pp.

Mizuno, T. (1964). Illustrations of freshwater plankton of Japan. Hoikusha. 351pp.

Mizuno, T. and Takahashi, E. (1991). An illustrated guide to Freshwater Zooplankton in Japan. Tokai University Press.

Park, K.S. and Shin, H.W.(2007). Studies on phytoand-zooplankton composition and its relation to fish productivity in a west coast fish pond ecosystem. J. Environ. Biol. : 28, 415-422.

Patrick, R. (1950). Biological measure of stream conditions. Sewage and Industrial Wastes, 22(7):926-93

Pejler, B. (1995). Relation to habitat in rotifers. Hydrobiologia. 313/314; 267-278. 
Reddy, Y.R. (1994). Copepoda: Calanoda: Diaptomidae: Guide to the identification of the microinvertebrates of the continental waters of the world. Vol.5 SPB Publishers, The Hague, Netherland.

Segers, H. (2007). Annotated checklist of the rotifers (Phylum Rotifera), with notes on nomenclature, taxonomy and distribution. Zootaxa. 1 564; 3-104.

Shannon, C.E. and Wiener, W. (1949). The mathematical theory of communication. University of Illinois Press Urbana, 125 pp.

Sharifun, N.I. (2007). Physicochemical Condition and Occurrence of Some Zooplankton in a Pond of Rajshahi University. Research Journal of Fisheries and Hydrobiology. 2(2): 21-25.

Sharma, M.S., Sharma, V. and Malara, H. (2007). Biodiversity of zooplankton in relation to different types of aquatic pollution. C.P. 46. NSL; 300-302.

Simpson, E. H. (1949). Measurement of diversity. Nature: $\quad 163-\quad 688$.

Sivalingam, P., Swamy, M. and Ravinder Reddy, T. (2013). International Research Journal of Biological Scienc Telesh, I. V. (2004). Plankton of the Baltic esturine ecosy: present knowledge and research prospectives. Mar. Verma, M.N. (1967). Diurnal variation in a fish pond in St

Victor, R. and Fernando, C.H. (1979). The fresh water ost of the zoological survey of India.74 (2): 147-242.

Ward, W.B. and Whipple, G. C. (1992). Freshwater biolog?

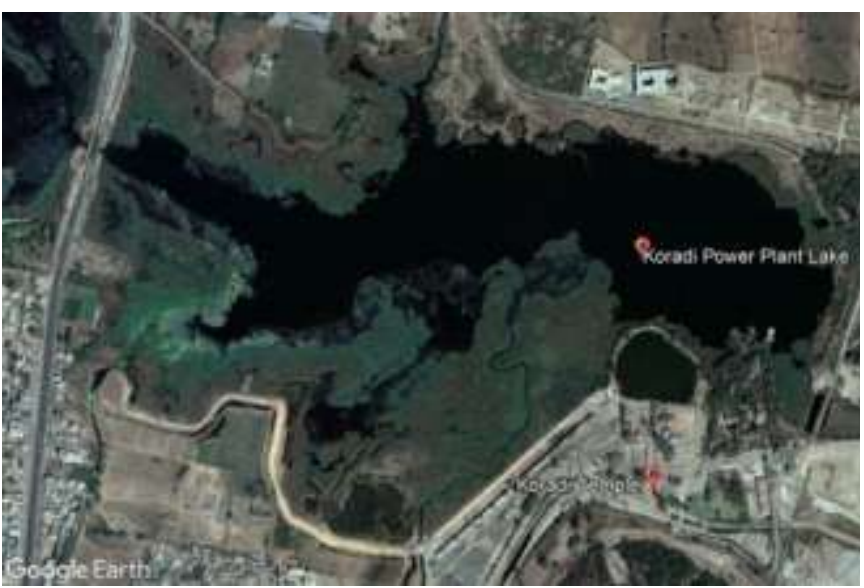

Figure 1: Map of the study area

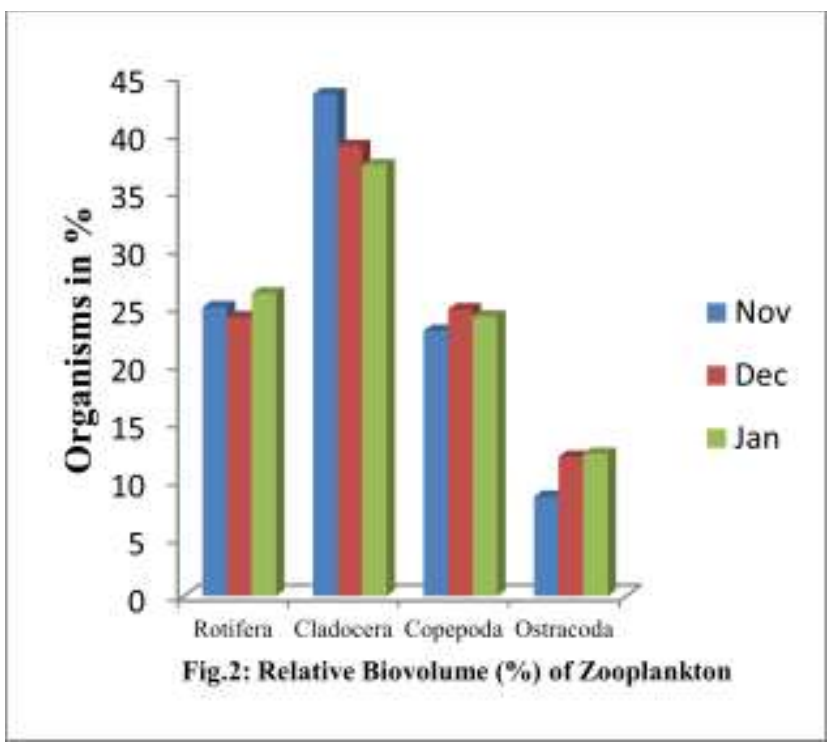

Welch, P.S. (1948). Limnology methods. McGraw Hill Boo. 
Table 1. Composition of Zooplanktons at Koradi Power Plant Lake

\begin{tabular}{|c|c|c|}
\hline Sr. & Group & Zooplankton \\
\hline \multirow{7}{*}{1} & \multirow{7}{*}{ Rotifera } & 1. Branchionus falactus \\
\hline & & 2. Branchionus angularis \\
\hline & & 3. Branchionus diversicornis \\
\hline & & 4. Branchionus plicatilis \\
\hline & & 5. Branchionus urceolaris \\
\hline & & 6. Keratella vulga \\
\hline & & 7. Lecane arculata \\
\hline \multirow{6}{*}{2} & \multirow{6}{*}{ Cladocera } & 1. Bosmmina longirostris \\
\hline & & 2. Alona rectangula \\
\hline & & 3. Daphnia pulex \\
\hline & & 4. Ceriodaphnia species \\
\hline & & 5. Chydorus species \\
\hline & & 6. Moina micrura \\
\hline \multirow{4}{*}{3} & \multirow{4}{*}{ Copepoda } & 1. Cyclops species \\
\hline & & 2. Diaptomus species \\
\hline & & 3. Mesocyclops species \\
\hline & & 4. Nauplius \\
\hline \multirow{3}{*}{4} & \multirow{2}{*}{ Ostracoda } & 1. Cypris \\
\hline & & 2. Stenocypris \\
\hline & Total Number of Organisms & 19 \\
\hline
\end{tabular}

Table 2. Composition of Zooplanktons in terms of density (Organisms/litre)

\begin{tabular}{|l|l|l|l|l|l|}
\hline \multirow{2}{*}{ Months } & \multicolumn{2}{|l|}{ Organisms/litre } & \multirow{2}{*}{ Total } \\
\cline { 2 - 5 } & Rotifera & Cladocera & Copepoda & Ostracoda & \\
\hline Nov & 61 & 106 & 56 & 21 & 244 \\
\hline Dec & 70 & 113 & 72 & 35 & 290 \\
\hline Jan & 66 & 94 & 61 & 31 & 252 \\
\hline
\end{tabular}

Table 3. a- diversity indices of Zooplaktons in Koradi Lake

\begin{tabular}{|l|l|l|l|}
\hline Month & December & January & February \\
\hline Total no. of organism & & & \\
\hline Simpson Index & 244 & 290 & 252 \\
\hline Dominance Index & 0.0688 & 0.0605 & 0.0698 \\
\hline Shannon Index & 0.9312 & 0.9395 & 0.9302 \\
\hline Menhinik Index & 3.985 & 4.08 & 3.977 \\
\hline Equitability Index & 1.216 & 1.116 & 1.197 \\
\hline Berger parker Dominance Index & 0.9376 & 0.9606 & 0.9362 \\
\hline Margulef Richard Index & 0.1148 & 0.0965 & 0.127 \\
\hline
\end{tabular}

